\title{
Menakar Pengaruh Modernisasi Dalam Implementasi Kebijakan Administrasi Pelayanan Publik Di Kota Kediri
}

\author{
${ }^{1}$ Heylen Amildha Yanuarita, ${ }^{2}$ Djoko Susanto
}

\author{
${ }^{1}$ Universitas Kadiri, Indonesia; heylenay@unik-kediri.ac.id \\ ${ }^{2}$ Universitas Kadiri, Indonesia; djokosusanto@unik-kediri.ac.id
}

\begin{abstract}
This research was conducted to analyze how modernization affects the implementation of public service administration policies, especially in Kediri, East Java. As is well known, from time to times various aspects of life are required to undergo changes to a more modern direction. The research method used is descriptive qualitative method. Descriptive qualitative research is aimed at obtaining an overview of how modernization affects public service administration policies in Kediri. To obtain the necessary data, the authors used a purposive sampling technique so that the sample taken was more focused, assisted by a review of several related previous studies. The results showed that modernization, especially in the field of technology, was sufficient to influence public service administration policies in Kediri.
\end{abstract}

Keywords: Implementation of Administration Policies, Modernization affect, Public service, Local Government

\section{Pendahuluan}

Pelayanan publik merupakan suatu pelayanan yang dilakukan di berbagai sektor publik, yang dijalankan oleh perangkat/aparatur pemerintahan, baik bentuk penyediaan barang atau jasa sesuai dengan kebutuhan yang diperlukan oleh masyarakat yang berasaskan pada aturan perundang-undangan yang diberlakukan. Dengan begitu, pemerintah memiliki peranan penting dalam menyediakan segala bentuk layanan publik. Adapun menurut Alamsyah (2011), pelayanan publik dimaknai sebagai segala aktivitas layanan yang dijalankan oleh organisasi, pemerintah, individu dan lainnya dalam upaya menjawab keinginan dari individu, kelompok, organisasi dan lainnya yang berkaitan dengan kepentingan masyarakat banyak.

Pada dasarnya, pelayanan publik merupakan suatu layanan yang diberikan kepada masyarakat yang menggunkan fasiltas umum yang disediakan, seperti jasa atau non-jasa yang dilaksanakan oleh organisasi publik atau disebut dengan lembaga pemerintahan. Untuk melaksanakan fungsinya yakni dalam memberikan pelayanan untuk masyarakat, pemerintah menerbitakn kebijakan yakni UU Nomor 25 Tahun 2009 Tentang Pelayanan Publik, yang mana memiliki tujuan untuk memaksimalkan kinerja layanan pemerintah sebagai upaya terciptanya pelayanan yang prima di setiap instansi pemerintahan. Salah satu bentuk pelayanan publik yang mesti dilakukan oleh pemerintah adalah soal kebijakan administrasi. Banyak masyarakat yang menganggap bahwa administrasi sering dikaitkan dengan kegiatan tatausaha dan keuangan, namun demikian administrasi sebetulnya tidak hanya itu. Maka dari tu sebagai masyarakat kita perlu tahun tentang suatu pelayanan administrasi yang merupakan bagian dari pelayanan publik yang dilakukan oleh instansi pemerintahan. Karena suaru kebijakan administrasi memiliki maksud untuk membantu dalam peningkatan layanan publik, pendataan, pembukuan dan pengarsipan, maka untuk itu dalam pelaksanaan kegiatan administrasi yang diberikan harus berorientasi pada pencapaian tujuan demi terciptanya kenyamanan dan kesejahteraan publik. 
Meskipun demikian, disadari atau tidak, dari waktu ke waktu masyarakat akan terus mengalami perubahan. Masyarakat dituntut agar bisa hidup seleras dan seimbang dengan kemajuan zaman yang terus terjadi. Ada beberapa aspek perubahan yang begitu cepat dan luas, adapula perubahan yang begitu lamban. Perubahan tersebut bisa dilihat dan dipahami oleh seseorang yang memiliki keinginan untuk meneliti susunan dan pola kehidupan suatu masyarakat pada masa wakt tertentu, kemudian membandingkanya dengan pola kehidupan masyarakat di masa yang lalu. Istilah perubahan dimkanai sebagai seseuatu yang menuju pada tatanan kehidupan yang baru kerap disapa sebagai modernisasi. Berkenaan dengan hal tersebut, sesungguhnya semua orang ingin memainkan pernnya dalam era modernisasi meskipun arah tujuan dan kecepatan dalam menjalankan aktivitas modernisasi yang tentunya memiliki perbedaan dengan yang lainnya. Proses suatu modernisasi bersifat sangat luas, baik cakupannya dalam aspek sosial, ekonomi, politik, budaya dan lainnya.

Secara khusus konsep modernisasi dipahami bersama oleh para pemikir modernisasi pada tahun 1950-an dan tahun 1960-an. Dimana konsep ini dipahami dalam 3 aspek, yaitu aspek historis, aspek relatif, dan aspek analisis. Secara definisi ditinjau dari aspek historis makna modernisasi memiliki makna yang sama dengan westernisasi/Amerikanisasi. Modernisasi dipandang sebagai suatu tindakan yang dilakukan untuk menuju cita-cita masyarakat sebagai suatu model. Sedangkan dilihat berdasarkan makan aspek relatif, modernisasi dimkanai sebagai upaya yang dilakukan untuk menyeimbangi suatu standar yang dipahami sebagai hal yang moderen baik oleh masyarakat umum maupun oleh para penguasa. Adapun pemaknaan berdasarkan aspek analisis memiliki ciri yang lebih khusus ketimbang dari dua aspek sebelumnya, yaitu meenggambarkan suatu ruang dimensi masyarakat yang moderen yang bertujuan untuk memahamkan pada masyarakat yang tradisional atau dikenal juga masyarakat pra-moderen (Sztompka, 2004). Adapun menurut Abdulsyani (1994), modernisasi dipahami sebagai suatu proses transformasi/ perubahan dari hal yang belum maju ke arah perubahan yang lebih atau arah peningkatan yang terjadi di setiap aspek kehidupan dalam masyarakat. Maka intinya bahwa suatu modernisasi merupakan proses yang mengalami perubahan dari hal dan cara yang tradisional ke hal dan cara yang lebih baru serta lebih maju, yang mana hal tersebut ditujukan untuk membantu dalam meningkatkan kesejahteraan masyarakat.

Saat ini, masyarakat Indonesia pun dituntut harus terlibat pada proses modernisasi ke arah digital. Seperti yang diketahui, hampir semua tatanan masyarakat beralih dari mode konvensional ke arah yang serba digital dengan memanfaatkan teknologi. Dalam hal ini perkembangan masa ke masa telah mengalami perubahan dengan penggunaan teknologi digital yang dilakukan di berbagai aspek kehidupan dalam aktivitasnya. Tidak terkecuali dengan masalah kebijakan administrasi yang dilakukan pemerintah untuk memaksimalkan pelayanan publik kepada masyarakat luas. Perubahan masalah kebijakan administrasi dan pelayanan publik ke sistem digital merupakan salah satu bentuk bahwa pemerintah ikut menyeleraskan dengan perkembangan zaman yang kian modern. Pelayanan publik sebetulnya berhadapkan dengan berbagai perubahan di setiap aspek kehidupan dalam masyarakat dan bernegara. Maka dari itu pemerintah tentu harus siap dalam merespon berbagai keingina yang diharapkan masyarakat dan tantangan perubahan zaman yang saat ini sudah mengenal teknologi yang diterapkan dalam kehidupan sehari-hari yang dipandang sebagai modernisasi.

Begitu halnya dengan salah satu kawasan di Provinsi Jawa Timur, yakni Kota Kediri. Termasuk pada salah satu daftar dari kota kecil dengan luas hanya $\pm 63,40 \mathrm{~km} 2$. Kawasankawasan kota kecil seringkali luput dari perhatian bagaimana kualitas dari pelayanan publik yang dilakukan pemerintah untuk masyarakat. Apalagi keadaan masyarakat yang semakin pintar memahami dan menerapkan teknologi serta terbuka dalam menerima informasi baru, 
mak tak heran masyarakat cenderung "menuntut lebih" terhadap suatu layanan publik yang didapatkan. Teknologi telah menggeser banyak hal dalam penyelenggaran pelayanan dalam berbagai aspek kehidupan. Maka untuk itu kemampuan memahami dan menerapkan suatu teknologi di zaman modernisasi ini merupakan unsur utama yang harus dimiliki suatu Instansi Pemerintahan. Karenanya perlu suatu kajian mendalam untuk menilai penggunaan teknologi yang dipergunakan dalam melakukan suatu layanan kepada masyarakat agar sesuai dengan yang masyarakat harapkan (DJKN Kemenkeu, 2020).

Oleh karena itu, pada penelitian kali ini, penulis ingin mengkaji dan menganalisis bagaimana pengaruh modernisasi terhadap pelayanan publik di Kota Kediri. Khususnya pada kebijakan administrasi masyarakat dalam mengakses semua pelayanan publik yang berkenaan dengan segala bentuk kebijakan keadministrasian. Serta mengetahui bagaimana tanggapan masyarakat akan pengaruh modernisasi tersebut terhadap implementasinya pada kebijakan administrasi pelayanan publik di Kota Kediri.

\section{Metode Penelitian}

Jenis penelitian yang digunakan dalam penelitian ini yakni metode kualitatif deskriptif. Menurut Sugiono (2016: 9) menyatakan bahwa penelitian kualitatif adalah sebuah penelitian yang menjadikan peneliti sebagai instrumen kunci, teknik pengumpulan data dilakukan dengan penggabungan dan analisis data bersifat induktif. Begitupun dengan Creswell (dalam Semiawan, 2010: 7) mendefinisikan bahwa penelitian kualitatif deskriptif adalah suatu penelitian yang dilakukan dengan menggunakan pendekatan atau pemantauan untuk mengekspolarasi dengan memahami suatu gejala yang terajadi. Penggunaan metode ini dilakukan agar penulis bisa mengetahui secara detail bagaimana pengaruh modernisasi terhadap kondisi pelayanan publik khususnya masalah kebijakan administrasi di Kota Kediri Jawa Timur. Selain itu, penelitian kualitatif pun bertujuan untuk memahami dari sudut pandang individu, menemukan penjelasan dari suatu gejala yang terjadi, dan menggali secara mendalam suatu informasi terhadap subjek penelitian (Putra, 2013: 44).

Untuk memaksimalkan penelitian, maka penulis perlu mengumpulkan berbagai data yang tepat dan sesuai dengan penelitian. Maka dari itu, penulis mengambil teknik pengambilan sampel secara tepat sasaran. Karena keterbatasan yang dialami oleh penulis untuk menjangkau semua populasi yang ada di Kota Kediri, maka penulis menggunakan teknik purposive sampling. Teknik ini diperuntukan pada pengambilan sampel secara khusus kepada orangorang yang memang memiliki kepentingan dan berkaitan dengan penelitian. Adapun stakeholders yang menjadi objek penelitian yaitu pihak-pihak terkait pemerintah setempat yang mengatur pelayanan publik di bidang administrasi, dan masyarakat yang merasakan layanan tersebut di Kota Kediri, Jawa Timur.

Sementara itu, untuk pengambilan data-data yang dibutuhkan dalam penelitian, penulis melakukannya dengan cara wawancara kepada pihak-pihak yang sudah dijadikan sampel. Meskipun begitu, sesuai dengan kebijakan pemerintah yang masih menganjurkan untuk membatasi kegiatan secara bebas selama pandemi, maka penulis mengambil langkah untuk melakukan wawancara secara online menggunakan media sosial seperti WhatsApp, Instagram dan pertemuan virtual via Zoom. Dalam penelitian ini menggunakan wawancara semiterstruktur dengan angket terbuka yang berisi beragam pertanyaan yang dapat diisi bebas oleh responden. Data-data yang sudah didapatkan kemudian diolah, dikaji, dan dianalisis agar memperoleh sebuah hasil simpulan penelitian. Untuk memaksimalkan hasil penelitian, penulis pun melakukan studi literatur sederhana dengan pemanfaatan dokumen yang sudah ada sebelumnya terkait dengan penelitian. 


\section{Hasil dan Pembahasan}

\section{Modernisasi Pelayanan Publik (Kebijakan Administrasi)}

Perubahan pada masyarakat pada dasarnya merupakan gejala tang biasa terjadi, dimana hal tersebut bisa berpengaruh dengan cepat yang tersebar luas dengan adanya komunikasi modern yang terjadi. Hal tersebut berkat adanya suatu penemuan terbaru terutama di bidang teknologi, perkembangan dan transformasi informasi melalui teknologi dapat tersampaikan pada masyarakat umum dimanapun berada dengan jangkauan yang luas.Adapun perubahan tersebut akan semakin cepat terjadi ditambah dengan kemunculan sarana prasarana penunjang modernisasi di bidang teknologi. Saat ini, perkembangan teknologi di dunia cenderung sangat cepat dan hampir mengubah tatanan hidup manusia ke arah yang lebih digital. Bahkan, masyarakat saat ini lebih dikenal dengan masyarakat era digital sebab selalu menyelipkan hal berbau digital dalam berbagai aspek kehidupan. Apalagi dengan banyak tersedianya smartphone dan akses jaringan internet yang tersedia dengan harga yang terjangkau dan mudah didapat.

Dari waktu ke waktu, jumlah pengguna internet di Indonesia relatif tinggi. Bahkan senantiasa mengalami perubahan. Berdasarkan data yang diambil dari DJKN Kemenkeu (2020) mengenai penelitian platform manajemen media sosial HootSuite dan agensi marketing sosial We Are Social bertajuk "Global Digital Reports 2020" yang terbit pada akhir bulan Januari 2020 mengatakan bahwa, jumlah para pengguna internet di Indonesia mencapai 175,4 juta orang, dengan total jumlah penduduk Indonesia berkisar 272,1 juta. Mkaa dari itu sekitar, $64,5 \%$ penduduk Indonesia sudah memiliki akses yang terhubung dengan internet. Jumlah pengguna internet di Indonesia disbanding tahun 2019 yang lalu mengalami peningkatan 175 atau 25 juta pengguna akses internet. Hal tersebut membuktikan, bahwa tinggi sekali minat masyarakat dalam menggunakan produk teknologi digital yang diakibatkan oleh modernisasi.

Seperti yang diketahui, masalah kebijakan administrasi merupakan bagian dari pelayanan publik. Kebijakan publik adalah suatu alterntif yang berupa pilihan yang dapat diambil (termasuk melakukan keputusan dengan tidak melakukan tindakan) yang dilakukan oleh pemerintah dalam menjalankan urusan tentang pemerintahan yang berkaitan degan publik. Kebijakan publik memiliki beberap unsur dasar yang tersiri dari tujuan yang jelas, sasaran yang terukur, dan cara yang tepat untuk mencapainya (Wibawa, 2011). Adapun Carl J Federick yang dikutip oleh Leo Agustino (2014) mengatakan bahwa kebijakan sebagai suatu rangkaian dari sebuah tindakan atau kegiatan yang dilakukan seseorang, kelompok atau pemerintah dalam keadaan tertentu yang memiliki kenda-kendala yang ditemui dan kesempatan yang diperoleh untuk mencapai suatu tujuan dari suatu kebijakan yang diharapkan.

Dalam mencapai sebuah tujuan dengan pemberlakuannya pelayanan publik, tentu pemerintah harus mengambil langkah-langkah tertentu yang sesuai dengan permintaan dan harapan masyarakat. Pemerintah juga harus ikut terjun dalam menyeleraskan pemberlakuan pelayanan publik tersebut sesuai dengan mengikuti perkembangan zaman. Begitu pun juga pemerintahan dibentuk antara lain untuk memajukan kesejahteraan umum dan mencerdaskan kehidupan bangsa sesuai dengan pembukaan undang-undang yang berlaku di Indonesia. Maka dalam hal ini negara memiliki peran dan tugas dalam memenuhi kebutuhan masyarakat sebagai upaya memberikan pelayanan yang prima dengan memenuhi kebutuhan yang diharapkan oleh masyarakat untuk mendapatkan layanan publik baik barang atau jasa dan layanan administratif lainnya.

Ada beberapa pelayanan administratif yang dilakukan dalam rangka memenuhi kebutuhan masyarakat banyak, seperti halnya yang sering dilakukan yakni pelayanan KTP, akte kelahiran, sertifikasi tanah, dan perizinan, sebagai penyelenggaraan pelayana sebagai 
upaya menjamin hak dan kebutuhan masyarakat dalam mendaptkan identitas sebagai warga negara. Pelayanan tersebut merupakan hal yang amat penting yang merupakan bagian dari pelayanan publik yang diselenggrakan oleh pemerintah untuk kepentingan publik. Namun demikian perkembangan pelayanan dari masa ke masa yang mengalami perubahan, terutama adanya fakor teknologi yang ikut andil dalam mempengaruhi pelayanan publik berbasis teknologi digital, tentu menjadi perhatian lebih bagi pemerintah untuk mempersiapkan pelayanan yang maksimal dakibat adanya modernisasi ini, yang tidak hanya terjadi di Indonesia melainkan diseluruh dunia.

\section{Implementasi Kebijakan}

Implementasi kebijakan adalah tahap yang penting dari suatu kebijakan, karena sebagus apapun suatu kebijakan tanpa diimplementasikan dan memberikan dampak yang diharapkan tidak akan bernilai baik dimata publik, maka dari itu implementasi suatu kebijakan harus memiliki hasil yang diharapkan oleh masyarakat. Secara pengertian luas implementasi kebijakan dipahami sebagai suatu alat administrasi publik yang terdiri dari beberapa unsur yakni adanya aktor, organisasi, prosedur, teknik serta sumber daya yang dikelola secara bersama untuk mencapai suatu tujuan yang diharapkan. Menurut George C. Edwards III dalam bukunya yang berjudul Implementing Public Policy yang mengatakan bahwa :

"Policy implementation, as we have seen, is the stage of policymaking between the establishment of a policy - such as the passage of a legislative act, the issuing of an executive order, the handing down of a judicial decision, or the promulgation of a regulatory rule -and the consequences of the policy for the people whom it affects." (Edwards III, 1980:01).

Dari kutipan tersebut bisa diketahui bahwa menurutnya, implementasi kebijakan metupakan tahapan pembuatan suatu kebijakan antara membentuk kebijakan sebagai tindakan yang dilakukan oleh legislatif, yang tentunya dibahas dengan badan eksekutif, serta disampaikan pula melalui keputusan peradilan, sebagai hasil suatu kebijakan yang memiliki dampak kepada orang-orang yang mempengaruhinya. Implementasi kebijakan tentunya adalah tahapan yang amat penting dalm suatu proses berjalannyanya suatu kebijakan, yang membantu dalam menentukan hasil dan dapak yang didapatkan dari suatu kebijakan. Adapun tahapan dalam proses implementasi kebijakan publik menurut Tachjian (dalam Mulyanto: 2016) adalah: (1) Perancangan (design) suatu kegiatan dengan tujuan yang snagat jelas, serta efesiensi waktu dan biaya. (2) Pelaksanaan (aplication) kegiatan melalui sumbedaaya yang tersedia atau sumber lainnya melalui metode tepatguna. (3) Pembangunan sistem monitoring dan pengawasan untuk menilai suatu keberhasilan kebijakan yang dilakukan.

Tahapan-tahapan tersebut bisa dilakukan oleh pemerintah untuk mencapai tujuan dan tentunya mencapai keinginan serta harapan masyarakat. Dengan pemberlakukan tahapan yang tepat, maka sebuah kebijakan bisa dikelola dan didayagunakan tepat guna dan tepat sasaran. Maka dari itu, pentingnya suatu kebijakan dapat diimplementasikan oleh para apartu pemerintah untuk memberikan suatu pelayanan prima kepada masyarakat, sehingga masyarakat dapat merasakan langsung layanan yang diberikan dan kepuasan yang diperolah dari pelayanan yang dilakukan pemerintah. 


\section{Pengaruh Modernisasi Pada Pelayanan Publik di Kota Kediri}

Seperti yang telah dikemukakan sebelumnya bahwa masyarakat saat ini sudah masuk era dunia baru atau tatanan dunia baru. Perkembangan teknologi yang begitu pesat, dan perubahan pola hidup masyarakat ke era digital, membuat semua aspek kehidupan pun harus turut serta terdigitalisasi. Kehadiran teknologi yang canggih, dunia yang mulai terdigitalisasi, adalah bentuk dari kehadiran modernisasi. Begitu halnya dengan masalah pelayanan publik. Di Indonesia sendiri, pemerintah sudah mulai mencanangkan penerapan industri 4.0 sejak beberapa tahun lalu. Hal ini sejalan dengan pendapat Holle (dalam Handika:2020) yang menyatakan bahwa hampi diseluruh pemerintahan di dunia, pelayanan publik ang dilakukan harus dilakukan secara efektif dan efisien serta membangun partisipasi aktif dari publik untuk merespon pelayanan berbasis teknologi diera modern seperti sekarang. Dalam kaitannya dengan industri 4.0 yang lebih moderen dengan perkembangan teknologi digitalnya, suatu pemerintah yang menjalankan aktivtas secara tradisional yang masih menggunakan paperbased administration sudah mulai digantikan dengan digital government berupa internet of things (IoT), dengan basis dimensi Big data.

Dewasa ini berkembang pesatnya berbagai inovasi dalam memberi suatu layanan publik untuk meningkatkan efiktifitas dan efisien serta akuntabilitas/pertanggungjawaban dengan dilakukannya metode baru sebagai alat baru dalam melakukan suatu pelayana publik (Mirnasari, 2013). Di Kota Kediri sendiri, pengaruh modernisasi terhadap pemberlakukan kebijakan administrasi dalam pelayanan publik sudah mulai terasa. Dikutip dari Suryamalang.com (2018), sistem pelayanan publik di setiap kelurahan Kota Kediri sudah terus diperbaiki. Selain memperbaiki ruang pelayanan di setiap kelurahan yang ada, juga sudah meluncurkan layanan online sistem berbasis android dan website yang bernama e-Suket. Dengan adanya layanan ini, masyarakat bisa mengajukan berbagai layanan publik secara online. Masyarakat tidak perlu datang ke kantor kelurahan, cukup dengan menggunakan e-Suket ini, maka pengurusan berbagai surat keterangan bisa dilakukan. Adapun alasan pembuatan layanan ini yakni pihak pemerintah setempat yang menyadari bahwa banyak warga atau masyarakat yang sibuk bekerja sehingga sulit ketika harus mengurus pemberkasan ke kantor kelurahan. Tentunya, dengan adanya layanan berbasis teknologi digital tersebut, bisa memudahkan masyarakat untuk mengurus pemberkasan dengan lebih efisien dan praktis.

Salah satu inovasi pelayanan publik adalaha E-Suket yang brkaitan dengan segala macam urusan pembuatan identitas berbasis online yang dilakukan oleh masyarakat Kota Kediri dalam mengurus kependudukan. E-suket ini membantu dalam layanan administrasi kependudukan yang berbentuk Kartu Tanda Penduduk (KTP) yang tentunya diperlukan oleh semua masyarakat. Dalam pelayanan yang diberikan oleh pemerintah dalam mengurusi KTP, tentu nya pemerinta memiliki kewajiban dalam melayani secara professional dan tanpa pandang bulu terhadap masyarakat. Adapun yang lainnya adalah layanan dalam pembuatan Surat Keterangan Tidak Mampu (SKTM), suarat keterangan, surat keterangan belum menikah, Kartu Identitas Anak (KIA), Surat Keterangan Catatan Kepolisian (SKCK), Surat Keterangan Kematian. Surat Keterangan Kelahiran, dan yang lainnya.

Berdasarkan Peraturan Wali Kota Kediri Nomor 44 Tahun 2018 Tentang Tata Kelola Teknologi Informasi dan Komunikasi di Lingkungan Pemerintah Kota Kediri. Pasal 4 huruf (c) dan (d) bahwa pemerintah Kota Kediri melakukan sinergitas dan pengoptimalan antar perangkat daerah dengan penyelenggaraan pemerintahan berbasis e-government dalam meningkatakn kualitas layanan publik sebagai wujud menciptakan tatakelola pemerintahan yang baik/ bersih yang dikenal dengan Good Governance and Clear Goverance melalui pemanfaatn teknologi informasi berbasis digital yakni Inovasi E-Suket menjadi inovasi Dinas Komunikasi dan Informasi Kota Kediri yang merupakan perintis dalam pemanfaatan teknologi 
berbasis online yang diterapkan dalam pelayanan publik, namun demikian secara input database layayan E-Suket dikelola langsung oleh Dinas Kependudukan dan Pencatatan Sipil Kota Kediri.

Selain itu, inovasi layanan E-Suket atau Elektronik Surat Keterangan ini merupakan salah satu implementasi dari gagasan Harmoni Kediri The Service City. Dimana gagasan ini memiliki peran menjadikan identitas suatu kota untuk memperkuat pengelolaan pelayanan publik yang dilakukan pemerintah dan menghilangkan pandangan pelayanan publik yang lama dan berbelit-belit (Rino, 2018). Adapun adanya pelayana publik ini memiliki tujuan dalam membantu mewujdukan peranan pemerintah daerah dari "Cuek-Bebal" menjadi pemerintah daerah yang memiliki orientasi dan bertanggung jawab penuh kepada publik. Apalgi Kota Kediri adalah kota yang beragam didalamnya, yang mana memiliki masyarakat dengan karakter yang ramah, sopan dan memiliki toleransi yang tinggi. Hal ini lah yang membuat Kota Kediri dikenal juga sebagai kota yang ama dan damai serta tentram baik anatar kelompok masyarakat yang ada, tanpa melihat antar agama dan antar etnis, yang tentunya dapat berjalan baik tanpa ada konflik/masalah dalam kehidupan bermasyarakat (Barometer, 2016).

Adanya hal ini, menjadikan kota Kediri memiliki branding baru yang dikenal dengan Harmoni Kediri The Service City, maka merespon hal tersebut Kota Kediri memberikan kemudahan akses bagi para pendatang yang berasal dari luar daerah untuk melakukan pelayanan seperti perizinan, kependudukan, kesehatan dan pelayanan publik lainnya yang menunjang peningkatan kinerja para birorkasi pemaritnatah atau aparatur pemrintah dalam menjalankan tugas dan tanggung jawabnya dalam melaksanakan layanan publik. Selain dari itu, berdasarkan Peraturam Wali Kota Kediri Nomor 44 Tahun 2018 Tentang Tata Kelola Teknologi Informasi Dan Komunikasi di Lingkungan Kota Kediri, yang menjelaskan tentang pengelolaan teknologi informasi daam mendukung layanan publik berbasis online, salah satunya dengan adanya surat keterangan berbasis digital yakni e-suket yang merupakan respon dari pemerintah setempat dalam menghadapi maslah yang dihadapi masyarkat dalam mengurusi identitas sebagai warga negara yang terkesan lama, maka dengan adanya pelayanan ini memudahkan dan memberika kenyamanan bagi masyarakat yang memerlukan.

\section{Respon Masyarakat Terhadap Pengaruh Modernisasi Pada Pelayanan Publik}

Selain melakukan peninjauan terhadap bagaimana kondisi dan pengaruh yang terjadi pada pelayanan publik di Kota Kediri akibat modernisasi ke arah perkembangan teknologi digital, maka penulis pun mencoba menakar bagaimana implementasi kebijakan tersebut jika ditilik dari sisi masyarakat. Seperti yang ditemukan pada pembahasan sebelumnya, Kota Kediri banyak menerapkan inovasi baru seiring dengan perkembangan teknologi. Terlebih ketika mulai diberlakukannya Service City. Mulai dari pembuatan layanan online E-Suket, hingga pihak Dinas Kependudukan dan Catatan Sipil Kota Kediri menjalankan beberapa inovasi dalam mewujudkan pelayanan yang maksimal agar memberikan kepuasan bagi masyarakat yang melakukan pelayanan, sepertihalnya inovasi pelayanan three in one yang membantu masyarakat dalam mengurus perubahan data penduduk, seperti akte kelahiran, kematian, perceraian dan pernikahan. Selain dari itu juga ada inovasi mobil pelayanan go-kling yang memanfaatkan fasilitas mobil keliling yang memiliki tugas dalam mendata data identitass kependudukan/KTP disetiap kelurahan sesuai ketentuan yang diatur sesuai kebijakan yang berlaku. 
Dalam penelitian, penulis mencoba mewawancarai sampel yang menjadi responden penelitian. Adapun pertanyaan inti yang ditanyakan oleh penulis kepada masyarakat adalah sebagai berikut:

1. Bagaimana kondisi sistem pelayanan publik khususnya di bagian pengurusan administrasi daerah setempat?

2. Apakah Bapak/Ibu sudah mengetahui perihal layanan online untuk mengurus berbagai surat-menyurat dengan praktis?

3. Bagaimana tanggapan Bapak/Ibu dengan layanan online yang diberlakukan oleh pemerintah?

Dari ketiga pertanyaan tersebut, maka jawaban dari semua sampel bisa diambil kesimpulan bahwa lebih banyak masyarakat di Kota Kediri yang menilai bahwa sistem pelayanan publik di daerahnya sudah cukup efektif. Termasuk perihal layanan administrasi seperti pembuatan KTP, akta kelahiran, akta nikah, dan lain sebagainya yang bisa dengan mudah dan cepat diurus. Para petugasnya pun sudah cukup tanggap dalam melayani permintaan dan kebutuhan masyarakat. Selain itu, meskipun sudah dalam kurun waktu lebih dari 2 tahun sejak diterbitkan layanan online E-Suket, namun masih banyak masyarakat di Kota Kediri yang belum mengetahui kehadiran aplikasi tersebut. Ada juga masyarakat yang sudah mengetahui aplikasi, namun memilih tidak menggunakannya karena dianggap kurang efektif dan memiliki kendala dengan teknis serta penggunaan. Meskipun begitu, masyarakat sangat mengapresiasi pihak pemerintah yang mau memberikan layanan prima kepada masyarakat. Terlebih juga pemerintah yang mau ikut serta dalam mengikuti perkembangan zaman agar lebih moderen dan tidak tertinggal dengan daerah lebih maju bahkan negara maju dan moderen. Begitu pun dengan apresiasi masyarakat yang mana pemerintah mau terus berinovasi untuk memberikan kemudahan bagi masyarakat.

Hasil wawancara tersebut pun sejalan dengan pemahaman Anis Epita (2016) bahwa adanya gagasan atau brand dari Harmoni Kediri The Service City dengan adanya dukungan memperbaiki penerapan kebijakannya dan inovasi baru dilakukan yang akan dirasakan oleh masyarakat langsung, dimana positioning Harmoni Kediri The Service City dipandang publik dirasakan sudah berhasil, karen bukan hanya mengetahui brand Harmoni Kediri The Service City sebagai suatu icon yang disampaikan di umum, tetapi juga merssakan kenyataannya langsung. Hal tersebut amatlah penting untuk membangun suatu kepercayaan dan emosional dari masyarakat kepada pemerintah Kota Kediri. Begitupun menurut Ahmada (2020), bentuk inovasi dari Pemerintah untuk membuat pelayanan publik secara online menjadi faktor yang perlu dan harus diapresiasi, mengingat tidak semua pemerintah di daerah lain menerapkan sistem penyelenggaraan secara online yaitu inovasi E-Suket (Elektronik Surat Keterangan). Sehingga Pemerintah Kota Kediri sebagai Lembaga tertinggi dapat mendengarkan apa yang dibutuhkan masyarakat dengan jawaban adanya inovasi E-Suket (Elektronik Surat Keterangan) yang sejalan dengan perkembangan teknologi yang mendigital. 


\section{Simpulan}

Dari hasil penelitian, penulis melihat bahwasanya Pemerintah Kota Kediri sudah siap tanggap dan seiring dengan perubahan zaman yang lebih modern. Pemerintah Kota Kediri, mampu memanfaatkan pengaruh modernisasi ini untuk membuat inovasi baru dalam meingkatkan kualitas pelayanan publik di Kota Kediri khususnya dalam masalah administrasi yang seringkali dikeluhkan. Bahkan, Pemerintah Kota Kediri pun bisa membuktikan pada masyarakatnya tentang gagasan kota service city atau kota pelayanan. Meskipun tidak semua masyarakat bisa mengakses layanan hasil inovasi akibat perkembangan teknologi tersebut, namun dengan ketanggapan pemerintah dalam membuat inovasi dan layanan untuk memudahkan masyarakat, itu sudah menjadi hal yang patut diapresiasi. Pasalnya, pelayanan yang cepat, tepat, dan tanggap ini menjadi kewajiban pemerintah untuk terus memberikan yang terbaik bagi warga Kota Kediri.

\section{Referensi}

Abdulsyani, (1994). Sosiologi, Skematika, Teori, dan Terapan, Jakarta: Bumi Aksara hlm 176177.

Agustino, L. (2014). Dasar-Dasar Kebijakan Publik. Bandung: CV Alfabeta

Ahmada. (2020). Inovasi Pelayanan Publik melalui penerapan Sistem Elektronik Surat Keterangan (E-SUKET) di Kota Kediri. Government: Jurnal Ilmu Pemerintahan. 13 (2). 105-11

Alamsyah. (2011). Manajemen Pelayanan Kesehatan. Yogyakarta: Nuha Medika

Barometer. (2016). Harmoni Kediri (Vol 7/ II). Kediri: Pemerintah Kota Kediri. Available from www.kedirikota.go.id [Accessed July 25, 2020].

DJKN Kemankeu. (2020). Mengkaji Ulang Pelayanan Publik di Era Digital. https://www.djkn.kemenkeu.go.id/artikel/baca/13128/MENGKAJI-ULANGPELAYANAN-PUBLIK-DI-ERA-DIGITAL.html

Epita, A. (2019). Strategi City Branding Kota Kediri Melalui 'Harmoni Kediri: The Service City". Commercium. 2 (2). 23-27

George. (1980). Implementing Public Policy. Congressional Quarterly Press.

Handika. (2020). Penerapan Teknologi Industri 4.0 Dalam Pelayanan Publik Di Bidang Administrasi Kependudukan (Studi Pelayanan Kartu Penduduk Elektronik Pada Dinas Kependudukan Dan Pencatatan Sipil Kabupaten Way Kanan). Jurnal Administrativa. 2 (1). 1-14

Mirnasari.(2013). Inovasi Pelayanan Publik UPTD Terminal Purabaya-Bungurasih. Universitas Airlangga. Volume 1 (1). 1-13

Mulyanto (2016). Penerapan Standar Pelayanan Publik Pada Kelurahan di Wilayah Kota Kediri. Jurnal Hasil Penelitian LPPM UNTAG Surabaya. 1 (2). 251-266

Putra, N. (2013). Penelitian Kualitatif IPS. Bandung: PT Remaja Rosdakarya

Rino. (2018). Implementasi Pelayanan Publik Berbasis Brand "Harmoni Kediri The Service City". Ekspektra: Jurnal Bisnis dan Manajemen. 2 (2). 140-156

Semiawan. (2010). Metode Penelitian Kualitatif. Jakarta: Grasindo 
Sugiyono. (2014). Metode Penelitian Pendidikan Pendekatan Kuantitatif, Kualitatif, dan R\&D. Bandung: Alfabeta

Surya Malang Tribunnews. (2018). Permudah Warga Kota Kediri Kenalkan Layanan Online Berbasis Android. Available from: https://suryamalang.tribunnews.com/2018/12/20/permudah-warga-kota-kedirikenalkan-layanan-online-berbasis-android [Accessed July 25, 2020].

Sztompka, P. (2002). Sosiologi Perubahan Sosial, Jakarta: Prenada, hlm 152-153.

Wibawa, S. (2011). Politik Perumusan Kebijakan Publik. Yogyakarta: Graha Ilmu 